\title{
MICHAŁ KOŁBUC
}

Uniwersytet Mikołaja Kopernika w Toruniu

michal.kolbuc@op,pl

ORCID: 0000-0002-8756-5471

\section{Skutki prawne naruszenia przez pracownika obowiązku trzeźwości}

The obligation to remain sober and the results of breaking this duty

Streszczenie. Obowiązek zachowania trzeźwości jest jednym $\mathrm{z}$ podstawowych obowiązków pracowniczych, pomimo że nie wynika on wprost z żadnego przepisu prawa pracy. Jednak jego naruszenie pociąga za sobą poważne konsekwencje na gruncie prawa pracy. Autor szczegółowo przedstawia źródło i zakres tego obowiązku oraz skutki prawne jego naruszenia.

Słowa kluczowe: praca; podstawowe obowiązki pracownicze; obowiązek trzeźwości.

Summary. To remain sober during the working hours is one of the basic duties of every employee although this obligation isn not regulated by labor law. However falling to full this duty may result in serious consequences for an employee on the grounds of labor law. The author shall present the details of this duty, including its sources, scope of application adn the effects of possible infingements.

Key words: work; basic employee duties; remain sober obligation.

Data przesłania artykułu do Redakcji: 24.04.2020 r.

Data akceptacji artykułu przez Redakcję: 20.07.2020 r.

\section{Wprowadzenie}

Zachowanie trzeźwości w miejscu i czasie świadczenia pracy jest jednym z podstawowych obowiązków pracowniczych. Tolerowanie przez pracodawcę zachowań sprzecznych z tym obowiązkiem może być poczytywane jako nieprzestrzeganie przez pracownika obowiązku zachowania bezpiecznych i higienicznych warunków pracy. Obowiązek ten wynika bowiem $\mathrm{z}$ art. 15 Kodeksu pracy $^{1}$ (dalej: KP), ma więc swoje źródło legalne i ze względu na swoją doniosłość, przez umieszczenie go w akcie prawnym rangi ustawowej powinien być bezwzględnie respektowany przez pracodawców.

Konsekwencje naruszenia przez pracownika obowiązku zachowania trzeźwości w miejscu i czasie wykonywania pracy mogą mieć różny charakter. Swoistym casus specialis $\mathrm{w}$ tej materii jest sytuacja, w której naruszenie zostało spowodowane chorobą alkoholową.

\footnotetext{
${ }^{1}$ Ustawa z dnia 26 czerwca 1974 r. Kodeks pracy (Dz. U. z 1974 r. nr 24, poz. 141 ze zm.), dalej: KP.
} 
Celem artykułu jest analiza skutków prawnych wynikających z naruszenia przez pracownika obowiązku trzeźwości w miejscu i czasie świadczonej pracy. Nie bez znaczenia dla tej analizy pozostaje także podstawa prawna weryfikowania trzeźwości oraz katalog organów uprawnionych do dokonywania kontroli trzeźwości. Szczegółowa analiza dotyczy konsekwencji prawnych naruszenia przez pracownika obowiązku zachowania trzeźwości. Tematyka praw i obowiązków pracownika oraz pracodawcy w procesie świadczenia pracy leży w zakresie zainteresowania wielu badaczy zarówno indywidualnego, jak i zbiorowego prawa pracy, którzy wskazują na jej duże znaczenie i doniosłość dla stron stosunków społecznych.

Artykuł powstał w oparciu o dostępne źródła prawa, orzecznictwo sądowe oraz literaturę przedmiotu. W pracy uwzględniono stan prawny na dzień 24 kwietnia 2020 roku.

\section{2. Źródło obowiązku zachowania trzeźwości w miejscu i czasie świadczenia pracy}

Na samym początku wyraźnego zaznaczenia wymaga fakt, że obowiązujący Kodeks pracy nie zawiera bezpośredniej regulacji dotyczącej obowiązku zachowania przez pracownika trzeźwości $\mathrm{w}$ miejscu oraz $\mathrm{w}$ czasie pracy. Z drugiej strony, należy także pamiętać, że zgodnie z art. $211 \mathrm{KP}$ do podstawowych obowiązków pracownika w zakresie zasad bezpieczeństwa i higieny pracy (dalej: BHP) należy przestrzeganie przepisów w zakresie BHP. Ustawa expressis verbis wskazuje, że jest to „podstawowym obowiązkiem pracownika” oraz zawiera katalog otwarty przesłanek, które wiążą pracownika. Katalog podstawowych obowiązków pracownika w zakresie BHP, określony w art. 211 pkt. 1-7 KP jest katalogiem otwartym za sprawą wyrażenia „w szczególności” użytego w jednostce redakcyjnej tego aktu prawnego.

Wśród tych powinności znajduje się obowiązek znajomości przepisów i zasad bezpieczeństwa i higieny pracy $^{2}$, a także obowiązek wykonywania pracy w sposób zgody z przepisami i zasadami BHP oraz obowiązek stosowania się do wydawanych w tym zakresie poleceń i wskazówek przełożonych ${ }^{3}$.

$\mathrm{Na}$ obowiązek bezpiecznego i higienicznego wykonywania pracy, szczególnie w kontekście zachowania trzeźwości, poza przepisami KP, wskazują także przepisy ustawy o wychowaniu w trzeźwości i przeciwdziałaniu alkoholizmowi ${ }^{4}$ (dalej: ustawa o wychowaniu w trzeźwości). Wśród przepisów tej ustawy kluczowe znaczenie dla obowiązku zachowania

\footnotetext{
${ }^{2}$ Zob. art. 211 pkt $1 \mathrm{KP}$.

${ }^{3}$ Zob. art. 211 pkt 2 KP.

${ }^{4}$ Ustawa z dnia 26 października 1982 r. o wychowaniu w trzeźwości i przeciwdziałaniu alkoholizmowi (Dz. U. z 1982 r. nr 35, poz. 230 ze zm.).
} 
trzeźwości przez pracownika mają: art. 14 ust. 1 pkt 2, art. 16, art. 17, art. 24, art. 40 oraz art. 44. Pierwszy z nich zabrania sprzedaży, podawania i spożywania napojów alkoholowych na terenie zakładów pracy oraz miejsc zbiorowego żywienia pracowników ${ }^{5}$, kolejne dotyczą wnoszenia napojów alkoholowych na teren zakładów pracy ${ }^{6}$, a także obowiązku ciążącego na kierowniku zakładu pracy lub na osobie przez niego upoważnionej związanego z niedopuszczeniem do pracy pracownika, co do którego zachodzi uzasadnione podejrzenie, że stawił się on do pracy w stanie po użyciu alkoholu albo spożywał alkohol w miejscu pracy $^{7}$. Następny z przepisów dotyczy uchylania się od pracy, które związane jest z nadużywaniem alkoholu ${ }^{8}$. Kolejne przepisy dotyczą $w$ pewnym sensie penalizacji zachowania, którego pracownicy dopuszczają się w stanie nietrzeźwości ${ }^{9}$.

\section{Gotowość do świadezenia pracy}

Zgodnie z art. 46 ust. 2 ustawy o wychowaniu w trzeźwości stan po użyciu alkoholu zachodzi wówczas, gdy alkohol w organizmie wynosi lub prowadzi do: stężenia we krwi od 0,2\%o do $0,5 \%$ albo obecności w wydychanym powietrzu od $0,1 \mathrm{do} 0,25 \mathrm{mg}$ alkohol w $1 \mathrm{dm}^{3}$. Z kolei zgodnie z art. 46 ust 3 przedmiotowej ustawy ze stanem nietrzeźwości mamy do czynienia wówczas, gdy zawartość alkoholu w organizmie wynosi lub prowadzi do: stężenia we krwi powyżej $0,5 \%$ alkoholu albo obecności w wydychanym powietrzu powyżej $0,25 \mathrm{mg}$ alkoholu $\mathrm{w} 1 \mathrm{dm}^{3}$.

Te dwie definicje są niezwykle istotne z punktu widzenia problemu związanego z zachowaniem i egzekwowaniem stanu trzeźwości w miejscu świadczonej pracy. Nie należy bowiem stawiać znaku równości między stwierdzeniem „stan po użyciu alkoholu” a „stan nietrzeźwości”.

$\mathrm{Na}$ tle tych dwóch pojęć trzeba także powiedzieć, że subiektywne odczucia pracownika co do jego dyspozycji do świadczenia pracy są bez znaczenia. Aby to wytłumaczyć, należy zastanowić się nad istotą stosunku pracy. Wielu przedstawicieli doktryny ${ }^{10}$ stoi na stanowisku, że świadczenie pracownika polega na oddaniu do dyspozycji swojej osoby w celu wykorzystania do wykonywania określonej pracy, a prawem i obowiązkiem pracodawcy jest odpowiednio (stosownie jednak do zawartej umowy)

\footnotetext{
${ }^{5}$ Zob. art. 14 ustawy o wychowaniu w trzeźwości.

${ }^{6}$ Zob. art. 16 ustawy o wychowaniu w trzeźwości.

${ }^{7}$ Zob. art. 17 ust. 1 ustawy o wychowaniu w trzeźwości.

${ }^{8}$ Zob. art. 24 ustawy o wychowaniu w trzeźwości.

${ }^{9}$ Zob. art. 40 i 44 ustawy o wychowaniu w trzeźwości.

${ }^{10}$ Taki pogląd prezentuje m.in. M. Święcicki, Niektóre sporne zagadnienia prawa pracy, Warszawa 1966, s. 78 oraz R. Korolec, Przerwy w świadczeniu pracy, Państwo i Prawo 1966, nr 7-8, s. 119-120, a także M. RafaczKrzyżanowska, Odpowiedzialność majątkowa pracownika wobec zakładu pracy, Warszawa 1969, s. 60.
} 
wykorzystać jego „siłę roboczą”. Gotowość do pracy w doktrynie i orzecznictwie określa się zazwyczaj jako pozostawanie pracownika przez obowiązujący go czas pracy w miejscu wykonywania pracy w stanie psychofizycznym umożliwiającym mu w każdej chwili, jeżeli tylko nie wystąpi (lub zniknie) przeszkoda, wykonywanie pracy. Jako konstytutywny element gotowości do pracy traktuje się zamiar jej wykonywania, gdy ustąpi przeszkoda. Można przyjąć, że istnieje faktyczne domniemanie istnienia takiego zamiaru, gdy pracownik doznający przeszkód w wykonywaniu pracy, ,trwa na posterunku pracy” w oczekiwaniu na ustąpienie przeszkody, zachowując psychiczną oraz fizyczną zdolność do jej wykonywania (w szczególności nie używa alkoholu ani narkotyków) ${ }^{11}$.

Pomimo że pracownik znajdujący się pod wpływem alkoholu może przejawiać wolę świadczenia pracy, absolutnie nie można powiedzieć, że znajduje się on w stanie gotowości do pracy. Takie stanowisko zajął także Sąd Najwyższy w wyroku z 11 kwietnia 2000 r.: „(...) stawienie się pracownika $\mathrm{w}$ miejscu wykonywania pracy $\mathrm{w}$ stanie nietrzeźwości wyklucza zarówno możliwość świadczenia przez niego pracy, jak też pozostawania w gotowości do jej świadczenia (...)"12.

Pracownik, który jest pod wpływem alkoholu, stanowi zagrożenia zarówno dla otoczenia w miejscu pracy (współpracowników, ewentualnych klientów, pracodawcy itd.), jak i dla samego siebie - szczególnie w sytuacji, gdy dla należytego i starannego wykonywania swojej pracy korzysta chociażby z niebezpiecznych narzędzi. Mając na uwadze okoliczność zapewnienia bezpieczeństwa w miejscu pracy, ustawodawca zdecydował się w art. 17 ustawy o wychowaniu w trzeźwości nałożyć na kierownika zakładu pracy lub osobę przez niego upoważnioną obowiązek niedopuszczenia do pracy pracownika, jeżeli zachodzi uzasadnione podejrzenie, że stawił się on do pracy w sranie po użyciu alkoholu albo spożywał alkohol w czasie pracy. Okoliczności stanowiące podstawę decyzji o odsunięciu takiej osoby od pracy powinny zostać jej podane. Ustawa nie precyzuje, jaka forma zawiadomienia o tym fakcie jest wymagana, ale ze względów dowodowych wydaje się najkorzystniejszym zastosowanie formy pisemnej.

Źródłem podejrzeń niezachowania przez pracownika obowiązku trzeźwości mogą być wszystkie jego niekonwencjonalne zachowania (np. chwiejny sposób poruszania się, niemożność utrzymania pionowej postawy ciała, zataczanie się, wyczuwalna woń alkoholu). Należy jednak pamiętać o tym, że art. $11^{1} \mathrm{KP}$ nakłada na pracodawcę obowiązek

\footnotetext{
${ }_{11}$ T. Liszcz, Gotowość do pracy, Publikacje Elektroniczne ABC, komentarz praktyczny dostępny online: https://sip.lex.pl/\#/publication/469830856 (dostęp: 23.04.2020).

${ }^{12}$ Por. wyrok SN z 11 kwietnia 2000 r., I PKN 586/99, OSNP 2001, nr 18, poz. 556.
} 
poszanowania godności i innych dóbr osobistych pracownika, dlatego tak ważne jest przeprowadzenie rzetelnej weryfikacji trzeźwości przez uprawnione do tego podmioty, w sposób który nie będzie urągał godności pracownika.

Podsumowując, aby pracownik został dopuszczony do wykonywania pracy musi się on znajdować w stanie gotowości do jej świadczenia (zarówno pod kątem fizycznym, jak i psychicznym). Dla niedopuszczenia pracownika do świadczenia pracy wystarczającym jest zatem sam fakt stwierdzenia, że w organizmie pracownika wystąpiło stężenie alkoholu w przedziale ustawowych limitów, o których wspomniano powyżej.

\section{Podmioty uprawnione do weryfikacji trzeźwości oraz sposób jej dokonywania}

Zgodnie z art. 17 ust. 3 ustawy o wychowaniu w trzeźwości na żądanie kierownika zakładu pracy, osoby przez niego upoważnionej, a także na żądanie pracownika badanie stanu trzeźwości pracownika przeprowadza uprawniony organ powołany do ochrony porządku publicznego. Zabiegu pobrania krwi dokonuje osoba posiadająca odpowiednie kwalifikacje zawodowe, a do badania stanu trzeźwości stosuje się przepisy wykonawcze wydane na podstawie art. 47 ust. 2 tej ustawy.

Zarówno KP, jak i ustawa o wychowaniu w trzeźwości nie regulują szczegółowo zasad i metod stosowanych przy weryfikacji trzeźwości pracowników. Aby poznać regulacje prawne dotyczące tej kwestii, należy w tym celu odwołać się do rozporządzenia Ministra Zdrowia i Ministra Spraw Wewnętrznych i Administracji ${ }^{13}$ (dalej: rozporządzenie z 28 grudnia 2018 r.), wydanego na podstawie art. 47 ust. 2 ustawy o wychowaniu w trzeźwości. Stanowi ono o warunkach oraz sposobie dokonywania badań w celu ustalenia zawartości alkoholu w organizmie, a także o sposobie ich dokumentowania oraz weryfikacji.

Zgodnie z $\$ 2$ powyższego rozporządzenia badania obejmują badanie wydychanego powietrza lub badanie krwi, a badanie wydychanego powietrza przeprowadza się przed badaniem krwi, jeżeli stan osoby badanej na to pozwala.

Organem uprawnionym, powołanym do ochrony porządku publicznego jest Policja lub Straż Miejska. Z badania przeprowadzonego analizatorem wydechu (alkomatem) u osoby badanej sporządza się protokół, którego zawartość określa $§ 7$ rozporządzenia z 28 grudnia 2018 r. Taki dokument będzie stanowił kluczowy dowód potwierdzający stan trzeźwości pracownika.

\footnotetext{
${ }^{13}$ Rozporządzenie Ministra Zdrowia i Ministra Spraw Wewnętrznych i Administracji z dnia 28 grudnia 2018 r. w sprawie badań na zawartość alkoholu w organizmie (Dz. U. z 2018 r. poz. 2472).
} 
Badanie krwi przeprowadza się, jeżeli osoba badana odmawia poddaniu się badaniu wydychanego powietrza, mimo przeprowadzonego badania wydychanego powietrza żąda badania krwi, stan osoby badanej uniemożliwia przeprowadzenie badania wydychanego powietrza lub wystąpił brak wskazania stężenia alkoholu spowodowany przekroczeniem skali w aparacie pomiarowym, co wynika z $§ 8$ rozporządzenia z 28 grudnia 2018 r. Badania krwi dokonuje osoba, która posiada odpowiednie ku temu kwalifikacje.

Kierownik zakładu pracy jest zobowiązany, na żądanie pracownika, zapewnić mu badanie wydychanego powietrza lub badanie krwi, a koszty związane $\mathrm{z}$ badaniami przeprowadzonymi na żądanie pracownika obciążają pracodawcę. Jeżeli wynik badania wykaże obecność alkoholu w organizmie pracownika, wówczas to on ponosi koszty z tym związane.

\section{Odmowa wykonywania pracy}

Zgodnie $\mathrm{z}$ art. $210 \mathrm{KP} \mathrm{w}$ razie, gdy warunki pracy nie odpowiadają przepisom BHP i stwarzają bezpośrednie zagrożenie dla zdrowia lub życia pracownika albo gdy wykonywana przez niego praca grozi takim niebezpieczeństwem innym osobom, pracownik ma prawo powstrzymać się od wykonywania pracy, zawiadamiając o tym niezwłocznie przełożonego.

Pracownik, naruszając obowiązek zachowania trzeźwości w miejscu oraz czasie świadczenia pracy, stwarza realne zagrożenie dla zdrowia i życia (zarówno swojego, jak i innych). Współpracownicy powinni bez jakiekolwiek zwłoki zawiadomić pracodawcę lub osobę, która jest przez niego upoważniona (np. kierownika zakładu pracy) o niedyspozycji podejrzanego pracownika; mają także obowiązek powstrzymania się od kontynuowania pracy. Stanowić to może bowiem przyczynę dla wystąpienia ujemnych w skutkach następstw - tak dla zdrowia, jak i życia tych ludzi.

\section{Konsekwencje prawne naruszenia przez pracownika obowiązku trzeźwości}

Pierwszą w KP i jak można się domyślać, najdonioślejszą w skutkach konsekwencją naruszenia przez pracownika obowiązku trzeźwości jest rozwiązanie umowy o pracę bez wypowiedzenia, będące jednostronną czynnością prawną (oświadczeniem woli), której skutkiem jest ustanie stosunku pracy (w zasadzie ze skutkiem natychmiastowym - z chwilą dojścia do wiadomości drugiej strony). Jak wynika $\mathrm{z}$ utartej linii orzeczniczej Sądu Najwyższego $^{14}$, oświadczenie tego typu nie może działać $\mathrm{z}$ mocą wsteczną. Jest to

\footnotetext{
${ }^{14}$ Wyrok SN z 19 października 1977 r., I PRN 107/77, Praca i Zabezpieczenie Społeczna 1979, nr 3, s. 65, a także wyrok SN z 6 października 1998 r., III ZP 31/98, OSNAPiUS 1999, nr 3, poz. 80, uchwała 7 sędziów SN
} 
nadzwyczajny sposób rozwiązania stosunku pracy, o drastycznych skutkach - zarówno w aspekcie społecznym, jak i ekonomicznym, podlegający ścisłej reglamentacji i dopuszczalny tylko w wyjątkowych okolicznościach (przewidzianych prawem), gdy niewskazane jest czekanie na ustanie stosunku pracy przez okres wypowiedzenia lub do upływu przewidzianego czasu trwania umowy ${ }^{15}$. Nieważna jest klauzula w umowie o pracę, upoważniająca pracodawcę do rozwiązania stosunku pracy ze skutkiem natychmiastowym bez podania przyczyny ${ }^{16}$.

Rozwiązać ze skutkiem natychmiastowym można umowę o pracę każdego rodzaju. Rozwiązać umowę o pracę bez wypowiedzenia może zarówno pracodawca, jak i sam pracownik.

Wśród podstaw uprawniających pracodawcę do zastosowania tego sposobu rozwiązania umowy o pracę KP wyróżnia dwie grupy: przyczyny zawinione przez pracownika (art. $52 \quad \S 1 \quad \mathrm{KP})$ oraz przyczyny niezawinione przez pracownika (art. 53 §1 i 2 KP). Pracodawca może rozwiązać umowę o pracę bez wypowiedzenia z winy pracownika w przypadku: (1) ciężkiego naruszenia podstawowych obowiązków pracowniczych, (2) popełnienia w czasie trwania umowy o pracę przestępstwa, które uniemożliwia dalsze zatrudnienie pracownika na zajmowanym stanowisku, (3) zawinionej utraty uprawnień koniecznych do wykonywania pracy na zajmowanym stanowisku.

Katalog podstawowych obowiązków pracowniczych nie został wyczerpująco uregulowany - ani w KP, ani w przepisach wykonawczych. Najważniejsze z nich, jak już wspomniano określa art. $100 \mathrm{KP}$, a pozostałe mogą być określone np. przez regulaminy pracy.

Naruszenie przez pracownika obowiązków pracowniczych stanowi uzasadnienie dla rozwiązania z nim stosunku pracy ze skutkiem natychmiastowym, jeżeli spełnione są dwie przesłanki - dotyczy ono obowiązków podstawowych oraz jest ciężkie. O ciężkości naruszenia obowiązków decydują przede wszystkim stopień winy pracownika (szczególnie: umyślność, rażące niedbalstwo) $^{17}$ oraz rozmiar szkody (wyrządzonej lub grożącej pracodawcy).

\footnotetext{
z 9 września 1999 r., III ZP 5/99, OSNAPiUS 2000, nr 4, poz. 131, wyrok SN z 12 lipca 2005 r., II PK 360/04, OSNP 2006, nr 7-8, poz. 110.

15 T. Liszcz, \$4. Rozwiazanie bez wypowiedzenia (ze skutkiem natychmiastowym), [w:] Prawo pracy, Wydawnictwo Wolters Kluwer - komentarz praktyczny dostępny online: https://sip.lex.pl/\#/monograph/369216467/32.

${ }^{16}$ Uchwała SN z 15 kwietnia 1994 r., I PZP 14/94, OSNAPiUS 1994, nr 3, poz. 140 z glosą B. Wagner, Przegląd Sądowy 1995, nr 6.

${ }^{17}$ Wyrok SN z 21 lipca 1999 r., I PKN 169/99, OSNAPiUS 2000, nr 20, s. 746.
} 
Kodeks pracy sprzed nowelizacji w 1998 r. $^{18}$, w art. $52 \S 1$ pkt 1 zawierał regulację następującej treści: „Zakład pracy może rozwiązać umowę o pracę bez wypowiedzenia z winy pracownika w razie: ciężkiego naruszenia przez pracownika podstawowych obowiązków pracowniczych, a w szczególności zakłócenia porządku i spokoju w miejscu pracy, opuszczania pracy bez usprawiedliwienia, stawienia się do pracy w stanie nietrzeźwości lub spożywania alkoholu w czasie pracy oraz dokonania nadużyć w zakresie korzystania ze świadczeń z ubezpieczenia społecznego lub innych świadczeń socjalnych". Nawet jednorazowe stawienie się $\mathrm{W}$ pracy $\mathrm{w}$ stanie nietrzeźwości lub spożywanie alkoholu w miejscu pracy (choćby nie prowadziło do nietrzeźwości) stanowiło podstawę do rozwiązania umowy $\mathrm{z}$ pracownikiem bez zachowania okresu wypowiedzenia. W wyniku nowelizacji $\mathrm{KP}^{19}$, treść art. 52 została zmieniona. Dotychczasowy katalog przestał ograniczać się jedynie do sytuacji wymienionych w ustawie, a nowe znamiona, które zostały wprowadzone także odnoszą się do naruszenia obowiązku zachowania trzeźwości przez pracownika w miejscu pracy.

Drugą konsekwencją naruszenia przez pracownika obowiązku zachowania trzeźwości jest możliwość zastosowania wobec niego kary porządkowej, którą przewiduje art. $108 \S 2 \mathrm{KP}$. Za nieprzestrzeganie przez pracownika przepisów BHP lub przepisów przeciwpożarowych, opuszczenie pracy bez usprawiedliwienia, stawienie się do pracy w stanie nietrzeźwości lub spożywanie alkoholu w czasie pracy - pracodawca może stosować karę pieniężną. Kara, o której mowa $\mathrm{w}$ tym przepisie, nie może być wyższa od jednodniowego wynagrodzenia pracownika, a łącznie kary pieniężne nie mogą przewyższać dziesiątej części wynagrodzenia przypadającego pracownikowi do wypłaty, po dokonaniu potrąceń, o których stanowi art. 87 §1 pkt 1-3 KP. Wpływy z kar pieniężnych przeznacza się na poprawę warunków BHP.

Konieczną przesłanką zastosowania odpowiedzialności porządkowej w stosunku do pracownika jest jego wina (umyślna lub nieumyślna). Nie ma znaczenia dla oceny zachowania czy naruszenie obowiązku przez pracownika wyrządziło szkodę $\mathrm{w}$ mieniu pracodawcy, gdyż kara pieniężna pełni funkcję represyjną i prewencyjną, a nie kompensacyjną. Zgodnie $\mathrm{z}$ art. $111 \mathrm{KP}$ przy stosowaniu kary bierze się pod uwagę w szczególności rodzaj naruszenia obowiązków pracowniczych, stopień winy pracownika i jego dotychczasowy stosunek do pracy. Jeżeli kara została zastosowana z naruszeniem

\footnotetext{
${ }^{18}$ Ustawa z dnia 26 czerwca 1974 r. - Kodeks pracy (Dz. U. z 1974 r. nr 24, poz. 141).

19 Mowa o ustawie z dnia 2 lutego 1996 r. o zmianie ustawy - Kodeks pracy i niektórych innych ustaw (Dz. U. z 1996 r. nr 24, poz. 110).
} 
przepisów prawa, pracownik może w ciągu 7 dni od zawiadomienia go o ukaraniu wnieść sprzeciw. Tryb postępowania w zakresie sprzeciwu szczegółowo reguluje art. 112 KP.

Odpowiedzialność materialna pracownika polega na obowiązku zapłaty odszkodowania w celu naprawienia szkody wyrządzonej pracodawcy przez niewykonanie lub nienależyte wykonanie obowiązku ze stosunku pracy. Od odpowiedzialności porządkowej odróżnia ją to, że konieczną przesłanką jej powstania jest wyrządzenie pracodawcy szkody. Dlatego zaznaczenia wymaga, że dodatkową okolicznością działającą na niekorzyść pracownika, który narusza obowiązek zachowania trzeźwości w miejscu i czasie świadczenia pracy jest fakt, że ,picie alkoholu w czasie pracy przez pracownika materialnie odpowiedzialnego wyłącza $\mathrm{z}$ reguły możliwość obniżenia przez sąd odszkodowania na podstawie art. $121 \S 2 \mathrm{w}$ związku z art. $127 \mathrm{KP}{ }^{, 20}$. Można wyobrazić sobie całkiem prawdopodobną sytuację, w której pracownik materialnie odpowiedzialny za powierzone mu przez pracodawcę mienie za sprawą swojego niedbalstwa i skrajnym naruszeniem obowiązków pracowniczych, wywołane niewypełnieniem obowiązku zachowania trzeźwości w miejscu pracy powoduje szkodę (np. spożywając w nadmiarze alkohol w miejscu pracy, w wyniku czego zasypia, czym pozwala na kradzież przez osoby trzecie powierzonego mu mienia).

W takim przypadku odszkodowanie za szkodę w mieniu powierzonym pracownikowi nie może być obniżone na zasadach określonych przez KP, co także tworzy dodatkową dolegliwość finansową dla pracownika naruszającego obowiązek zachowania trzeźwości.

Podsumowując, pracodawca powinien wyciągać konsekwencje prawne w stosunku do pracowników naruszających obowiązek zachowania trzeźwości w miejscu i czasie pracy. Cel takiego działania jest dwojaki - z jednej strony ma służyć stworzeniu dolegliwości (ukaraniu) ekonomicznej dla pracownika, $\mathrm{z}$ drugiej strony ma być działaniem o charakterze prewencyjnym w celu zapobieżenia występowania podobnych przypadków w przyszłości.

Środki, które powinny znaleźć zastosowanie w pierwszej kolejności są określone przez art. 108 KP (kary porządkowe), które w zależności od oceny konkretnego przypadku powinny być wykorzystywane przez pracodawcę w postaci kary upomnienia lub kary nagany. Jak już wspomniano, swoisty lex specialis dla ogólnej regulacji kar porządkowych stanowi art. $108 \S 2 \mathrm{KP}$, który reguluje kwestię rodzaju kary stosowanej w przypadku pracownika stawiającego się do pracy w stanie nietrzeźwości lub spożywającego alkohol w czasie pracy.

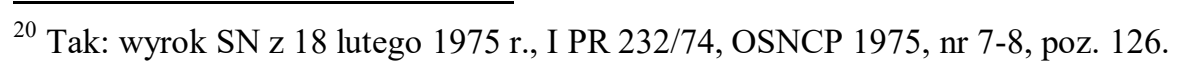


W zależności od oceny konkretnego przypadku, a np. w sytuacji, gdy pracownik po raz kolejny naruszył obowiązek zachowania trzeźwości w miejscu pracy, pracodawca ma prawo rozwiązać z nim stosunek pracy, stosując w tym celu regulację art. $52 \S 1 \mathrm{KP}$. Musi jednakże wziąć pod uwagę, czy zostały spełnione przesłanki, o których była mowa wcześniej.

Nieuprawnionym byłoby stwierdzenie, że absolutnie każdy przypadek, gdy pracownik narusza obowiązek zachowania trzeźwości należy klasyfikować jako zawinione. Taki wyjątek stanowi choroba alkoholowa pracownika. W takiej sytuacji problem w ustaleniu, czy wystąpienie u takiego pracownika stanu nietrzeźwości to jego wina, czy stanowi następstwo choroby. Jak wynika z orzeczenia Sądu Najwyższego ${ }^{21}$, osoba, która cierpi na chorobę alkoholową, może naruszyć pracowniczy obowiązek zachowania trzeźwości w miejscu pracy nie ze swojej winy, w związku z niemożnością powstrzymania się od spożycia alkoholu niezależnie od miejsca i czasu. Sąd Najwyższy szczególnie wskazywał na przypadek, gdy pracownik jest we wstępnej fazie psychozy alkoholowej, przez co ma ograniczoną zdolność kierowania swoim postępowaniem, a co z kolei powoduje niemożność powstrzymania się od spożywania alkoholu. Słusznie wskazał także na okoliczność, że każdy przypadek wymaga indywidualnej oceny.

Istnieją także sytuacje, na podstawie których pracodawca nie będzie mógł wyciągać konsekwencji spożywania alkoholu w miejscu i czasie świadczenia przez pracownika pracy. Niewątpliwie do takich zaliczyć można zdarzenia o charakterze zwyczajowym - np. toast wznoszony lampką szampana z okazji, na której obecny jest pracodawca. Nie powinny one jednak stanowić podstawy do pociągania pracownika do odpowiedzialności z tytułu niedopełnienia obowiązku zachowania trzeźwości.

Należy mieć także na uwadze, że wszelkie tego rodzaju ,przyzwolenia” na tzw. symboliczną lampkę szampana powinny być stosowane ze szczególną rozwagą, ponieważ formalnie stanowią one naruszenie obowiązków, o których stanowi ustawa o wychowaniu $\mathrm{w}$ trzeźwości. W takim obrocie spraw, nie dają się pogodzić spotkania pracowników (nawet po godzinach pracy, ale odbywające się w miejscu pracy) z obowiązkiem zachowania przez nich trzeźwości w miejscu świadczenia pracy. Taki pogląd został wyrażony przez Sąd Najwyższy w jednej z jego uchwał ${ }^{22}$.

Konkludując, można stwierdzić, że choroba alkoholowa pracownika wyłącza możliwość przypisania mu winy, a tym samym ciężkiego i zawinionego naruszenia podstawowych obowiązków pracowniczych. Wszelkie tego rodzaju przypadki należy badać

\footnotetext{
${ }^{21}$ Wyrok SN z 10 października 2000 r., I PKN 76/00, OSNP 2002, nr 10, poz. 237.

${ }^{22}$ Uchwała SN z 27 października 1986 r., VI KZP 19/86, OSNKW 1987, nr 3-4, poz. 24.
} 
indywidualnie, mając na uwadze wyrażony $\mathrm{w}$ art. $11^{1}$ Kodeksu pracy obowiązek poszanowania dóbr osobistych pracownika, w tym jego godności.

\section{Podsumowanie}

Zachowanie trzeźwości jest jednym z podstawowych obowiązków pracownika, a jego naruszenie uzasadnia podjęcie przez przełożonych kroków służących jego zdyscyplinowaniu. Mogą one przyjmować różne formy - od odpowiedzialności porządkowej, po rozwiązanie umowy w trybie art. $52 \S 1$ Kodeksu pracy. Aby działania podjęte przeciwko nietrzeźwemu pracownikowi były legalne oraz odpowiednio udokumentowane, należy stosować komplementarnie przepisy Kodeksu pracy, ustawy o wychowaniu w trzeźwości oraz odpowiednie akty wykonawcze do tych ustaw. W sprawach dotyczących naruszenia przez pracownika obowiązku zachowania trzeźwości pod względem dowodowym najlepiej zachować formę pisemną.

W razie uzasadnionego podejrzenia, że pracownik może być nietrzeźwy, pracodawca ma bezwzględny obowiązek nie dopuścić do go świadczenia pracy - przede wszystkim ze względu na bezpieczeństwo jego i innych pracowników. Jednocześnie powinien poinformować takiego pracownika o powodach, dla których nie dopuścił go do pracy.

Mimo że nietrzeźwość w pracy stanowi przykład ciężkiego naruszenia podstawowych obowiązków pracowniczych, uzasadniającego rozwiązanie stosunku pracy bez wypowiedzenia, należy mieć na uwadze także sytuację osób dotkniętych chorobą alkoholową.

Z punktu widzenia zatrudnionych tolerowanie przez pracodawcę naruszeń obowiązku zachowania trzeźwości w miejscu i czasie świadczenia pracy może być odbierane jako nieprzestrzeganie przez niego obowiązku zapewnienia bezpiecznych i higienicznych warunków pracy, co niewątpliwie jest zjawiskiem niepożądanym. Dlatego tak ważna jest reakcja ze strony pracodawcy na mające miejsce naruszenia tego obowiązku, bowiem to do niego należy zachowanie zasad BHP w miejscu pracy.

\section{Bibliografia:}

\section{Akty prawne}

Ustawa z dnia 26 czerwca 1974 r. Kodeks pracy (Dz. U. z 1974 r. nr 24, poz. 141 ze zm.)

Ustawa z dnia 26 października 1982 r. o wychowaniu w trzeźwości i przeciwdziałaniu alkoholizmowi (Dz. U. z 1982 r. nr 35, poz. 230 ze zm.)

Rozporządzenie Ministra Zdrowia i Ministra Spraw Wewnętrznych i Administracji z dnia 28 grudnia 2018 r. w sprawie badań na zawartość alkoholu w organizmie (Dz. U. z 2018 r. poz. 2472) 


\section{Literatura}

Korolec R., Przerwy w świadczeniu pracy, Państwo i Prawo 1966, nr 7-8

Liszcz T., Gotowość do pracy, Publikacje elektroniczne ABC (dostęp online 23.04.2020): https://sip.lex.pl/\#/publication/469830856

Liszcz T. Prawo pracy, Warszawa 2019

Rafacz-Krzyżanowska M., Odpowiedzialność majątkowa pracownika wobec zakładu pracy, Warszawa 1969

Święcicki M., Niektóre sporne zagadnienia prawa pracy, Warszawa 1966

\section{Orzecznictwo}

Wyrok SN z 12 lipca 2005 r., II PK 360/04, OSNP 2006, nr 7-8, poz. 110

Wyrok SN z 10 października 2000 r., I PKN 76/00, OSNP 2002, nr 10, poz. 237

Wyrok SN z 11 kwietnia 2000 r., I PKN 586/99, OSNP 2001, nr 18, poz. 556

Uchwała 7 sędziów SN z 9 września 1999 r., III ZP 5/99, OSNAPiUS 2000, nr 4, poz. 131

Wyrok SN z 21 lipca 1999 r., I PKN 169/99, OSNAPiUS 2000, nr 20, s. 746

Wyrok SN z 6 października 1998 r., III ZP 31/98, OSNAPiUS 1999, nr 3, poz. 80

Uchwała SN z 15 kwietnia 1994 r., I PZP 14/94, OSNAPiUS 1994, nr 3, poz. 140

Uchwała SN z 27 października 1986 r., VI KZP 19/86, OSNKW 1987, nr 3-4, poz. 24

Wyrok SN z 19 października 1977 r., I PRN 107/77, Praca i Zabezpieczenie Społeczna 1979, nr 3, s. 65

Wyrok SN z 18 lutego 1975 r., I PR 232/74, OSNCP 1975, nr 7-8, poz. 126 